duties on vegetables, fruits, and flowers. One of the effects of this order will be to keep out luxury products, and will give gardeners an opportunity of capturing a market which has hitherto been beyond their reach. There is now to be a duty of eight shillings per cwt. on all foreign. lettuce from Jan. 1 until April 30. It is easy to compute the exact cost of the electric installation required; and where electricity is cheap, much can be said in its favour.

\section{International Industrial Agreements}

IN a general report on the economic aspects of international industrial agreements recently prepared for the Economic Committee of the League of Nations, it is concluded that international agreements constitute an important attempt to remedy certain disadvantages of the present economic evolution. They are not a panacea and do not apply to all products; they may mitigate but not abolish economic crises. Like other human institutions, they are liable to error and even abuse, but experience has shown that they quickly pay for any mistaken policy, and a false ster may even imperil their existence. When of long duration, their interest definitely coincides with the general interest, for example, in stabilising at moderate prices, eliminating dumping, stabilisation of customs duties, and of employment, and in minimising the fall of wages in periods of depression. The advantages of lower costs to producers are secured in various ways, such as regular production, diminution and standardisation of stocks, elimination of unnecessary transport, economies and increased efficiency in research and other technical matters, patents, marketing, sales organisation. The advantages of greater equilibrium between production and consumption and of relative stability in prices are equally beneficial to producer and consumer. Agreements do not eliminate competition, but the limitations they impose on competition are beneficial, as avoiding waste or destruction of capital. The existence of international agreements did not create the present crisis; on the contrary, the seriousness of the crisis intensified the movement for such agreements to mitigate its consequences. They are accordingly considered to constitute a valuable guarantee of the economic and political stability of the nations.

\section{North American Oyster Fisheries}

Mr. H. P. SHerwood who, during 1930, was sent by the English Ministry of Agriculture and Fisheries to investigate the American methods of oyster culture, in his paper "The Oyster Industry in North America : a Record of a Brief Tour of some of the Centres on the Atlantic and Pacific Coasts, and of a Summer in Canada" (J. Conseil, vol. 6, No. 3, Dec. 1931), gives an interesting account of the industry in North America and the various beds visited. He spent a summer in Canada, working on oyster investigations in Malpeque Bay, Prince Edward Island, and also visited most of the oyster-raising areas on both coasts of the United States. Recent figures put the annual yield of the oyster industry in North America at about 73,000 tons of food, valued at more than
14,000,000 dollars. The oysters belong to large and small companies and individual owners of oyster schooners, or oystermen, who fish in shallow reserved portions of the public beds. The natural beds of Ostrea virginica on the Atlantic coast at one time flourished from Maine to Mexico, but have greatly dwindled, and on the Pacific coast the industry is now practically confined to inlets in the State of Washington. Cultivation lies chiefly in providing in the summer clean shell cultch on the beds for attachment of the larvæ, culling or separating and sorting oysters from clusters in the clutch, and planting spat and half-grown oysters, together with measures for destroying pests. There is a demand for a greatly increased supply of seed oysters in many of the oyster-growing areas, although natural falls may in some seasons be very prolific. A few years ago this stimulated renewed interest in the problem of raising spat artificially, but more recently research has been directed to extending the possibilities of securing good sets of natural spat and to destroying pests, rather than to developing hatchery methods.

\section{The Gulf Stream}

THE results of investigations on the behoviour of the Gulf Stream were communicated to a recent meeting of the American Geographical Union at Washington by Mr. P. E. Church. According to Science Service, Mr. Church discovered many irregularities in width and temperature but no clear seasonal fluctuations. The data were obtained by recording instruments installed on commercial vessels crossing the triangle of waters between Halifax, Bermuda, and the Georgian coast. Inshore water extends to about the hundred-fathom line, beyond which is a wide area of cool water, ending in a narrow band of cold water believed to be due to upwelling from the depths. The Gulf Stream lies beyond, and was found to be 50 miles wide off Cape Hatteras and not more than 70 miles wide south of Nova Scotia. Outside the Gulf Stream to the south-east lies a broad area of warm water reaching towards mid ocean. During the winter months, and occasionally at other seasons, the Gulf Stream flows as a double stream, with a tongue of cold water between, which may pinch off the northern stream and push the main stream considerably southward. Mr. Church does not explain this deviation, but doubts if wind action is the cause. South of Halifax the northern edge of the Gulf Stream averages a distance of 290 miles offshore but varies between 230 and 420 miles.

\section{Science and the Empire}

THe July number of Discovery is devoted, in view of the Ottawa Conference, to the subject of science and the Empire. Sir Stephen Tallents manages to give in a very few pages a vivid picture of the varied scientific activities which, on the confines of the Empire, become particularly associated with agriculture, the mainstay of dominions and colonies alike. The close contact maintained between scientific work at different centres is emphasised in this review and 